\title{
Pathogenicity of Rhodococcus equi in mice, isolated from environment, human and horse clinical samples ${ }^{1}$
}

\author{
Mateus M. Costa ${ }^{2}$, Sérgio A. Machado ${ }^{3}$, Cristina C. Krewer ${ }^{2}$, Márcia R.S. Ilha ${ }^{4}$, \\ Dominguita L. Graça ${ }^{5}$, Ana L.M. Guaraldi ${ }^{6}$ and Agueda C. Vargas ${ }^{7 "}$
}

\begin{abstract}
Costa M.M., Machado S.A., Krewer C.C., Ilha M.R.S., Graça D.L., Guaraldi A.L.M. \& Vargas A.C. 2006. Pathogenicity of Rhodococcus equi in mice, isolated from environment, human and horse clinical samples. Pesquisa Veterinária Brasileira 26(3):167-170. Laboratório de Bacteriologia, Departamento de Medicina Veterinária Preventiva, Centro de Ciências Rurais, Universidade Federal de Santa Maria, Avenida Roraima 1000, Santa Maria, RS 97105-900, Brazil. Email: agueda@ccr.ufsm.br

Rhodococcus equi is a facultative intracellular pathogen associated with bronchopneumonia, mesenteric lymphadenitis and enterocolitis in foals. Although $R$. equi is likely to be found in every horse-breeding farm, the clinical disease is unrecognized in most of them. Capsule components, equi factor, micolic acid and some products encoded by the large $85-90 \mathrm{~Kb}$ plasmid were described as virulence factors. However, the pathogenesis of $R$. equi infections and the sensibility of foals are not completely understood. The aim of this study was evaluate the virulence of R. equi isolated from human, horses and environment for mices. Nine strains carrying the $85-90 \mathrm{~Kb}$ plasmid isolated from foal clinical specimens, one from immunodeficient human patient and six plasmidless strains (four isolated from feces, one from pasture and one from immunodeficient human patient) were inoculated in cyclophosphamide immunossuppressed mice. The pathological changes and viability of $R$. equi cells in the liver of mice was verified after the 3rd, 6th an 10th day after inoculation for horse and environmental isolates and for $R$. equi isolates from human patients on the $1 \mathrm{st}$, 3rd and 6 th day. During the necropsy procedures, infiltrate of macrophages and pyogranulomatous lesions were detected after the sixth pos-inoculation day in the liver and spleen. In horse isolates, only plasmid positive strains were virulent, but in human isolates both strains (plasmid positive e plasmid negative) were virulent. Both groups of the immunossupressed mice inoculated with $R$. equi isolated from environment showed pathological changes. All $R$. equi strains were unable to kill non imunossuppressed mice.
\end{abstract}

INDEX TERMS: Rhodococcus equi, mice, virulence, cyclophosphamide.

\footnotetext{
${ }^{1}$ Received on October 21, 2005.

Accepted for publication on February 15, 2006.

2 Programa de Pós-Graduação em Biologia Celular e Molecular, Centro de Biotecnologia, UFRGS, Porto Alegre, RS 91540-000.

${ }^{3}$ Programa de Pós-Graduação em Medicina Veterinária, Universidade Federal de Santa Maria (UFSM), Santa Maria, RS 97105-900.

${ }^{4}$ Médico Veterinário. Rua Paissandu 385, Apto 201, Flamengo, Rio de Janeiro RJ 22210-080

${ }^{5}$ Depto Patologia, Universidade Federal de Santa Maria (UFSM), Santa Maria, RS 97105-900.

${ }^{6}$ Centro Biomédico, Faculdade de Ciências Médicas, Universidade do Estado do Rio de Janeiro, Av. 28 de Setembro 87, Vila Izabel, Rio de Janeiro, RJ 20551-030.

${ }^{7}$ Depto Medicina Veterinária Preventiva, Universidade Federal de Santa Maria (UFSM), Santa Maria, RS 97105-900. "Corresponding author: agueda@ccr.ufsm.br
}

RESUMO.- [Patogenicidade em camundongos de isolados clínicos, ambientais e humanos de Rhodococcus equi.] Rhodococcus equi é um patógeno intracelular facultativo associado com broncopneumonia, linfadenite mesentérica e enterocolite em potros. Apesar do patógeno ser amplamente distribuído no ambiente equino, a doença não é encontrada em todos os criatórios. Componentes capsulares, "fator equi", ácido micólico e alguns produtos codificados por um grande plasmídeo de $85-90 \mathrm{~Kb}$ foram descritos como fatores de virulência. Entretanto, a patogênese da infecção e a susceptibilidade dos potros não são completamente entendidas. Nove cepas carreando o plasmídeo e isoladas de potros doentes, um isolado de paciente humano imunossuprimido, e seis cepas sem plasmídeo ( 4 de fezes, 1 de pastagem e 1 de paciente humano imunossuprimido) foram inoculadas em camundongos imunossuprimidos com ciclofosfa- 
mida. As alterações patológicas e a viabilidade das células de $R$. equi no fígado foram verificadas depois do terceiro, sexto e décimo dia após a inoculação para isolados clínicos e depois do primeiro, terceiro e sexto dia para isolados de pacientes humanos. Na necropsia foram detectados infiltrado de macrófagos e lesões piogranulomatosas no fígado e baço dos camundongos após o sexto dia da inoculação. Para isolados clínicos, somente os plasmídeo positivos foram virulentos, mas para os humanos, ambos os isolados (plasmídeo positivos e plasmídeo negativos) foram virulentos. Ambos os grupos de camundongos imunossuprimidos inoculados com isolados ambientais mostraram alterações patológicas. Todos os isolados foram incapazes de matar camundongos imunocompetentes.

TERMOS DE INDEXAÇÃO: Rhodococcus equi, camundongos, virulência, ciclofosfamida.

\section{INTRODUCTION}

Rhodococcus equi is a pleomorphic coccobacillus gram positive bacteria, usually found in the gastrointestinal tract of horses. It has been recognized as an important pathogen due to reports of $3 \%$ of foal deaths widespread in the world (Takai et al. 1993, Sellon et al. 2001). R. equi is a major lung pathogen in less than 6month-old foals with high mortality (Ozgur et al. 2000). The pneumonia induced by $R$. equi may also occur in adult horses, particularly in immunocompromised individuals, when it causes systemic infections (Takai et al. 1996).

Nowadays, $R$. equi has also been increasingly related as opportunistic pathogen of human immunocompromised patients, especially HIV reactor, although infections in immunocompetent hosts may occur (Kedlaya et al. 2001). However, little is known about the characteristics of $R$. equi strains isolated from humans. Cryptic plasmids of various sizes and fimbrial structures were detected frequently suggesting the antibiotic resistance (Nordmann et al. 1994). The majority of clinical isolates of $R$. equi from imunossuppressed human patients did not carry virulence plasmids and were no virulent to mice, suggesting that the pathogenesis of $R$. equi infections in immunossupressed hosts may be different from that which occurs in foals (Meijer et al. 2004).

Despite of the importance of $R$. equi disease, its pathogenesis and the singular sensibility of foals are not completely understood (Takai et al. 1993, Takai et al. 1999). The pathogenicity varies among strains and it is associated with the ability of $R$. equi to resist pulmonary and splenic clearance (Hines et al. 1997, Hondalus et al. 1994). Virulence of $R$.. equi has been related to several microbial factors, as capsular antigens, equi factor, micolic acid from cell wall, and the thermoregulated $15-17 \mathrm{kDa}$ protein (VAP A) encoded by the 85-90Kb plasmids. Guiguerre et al. (1999) showed that the presence of the $85-90 \mathrm{~Kb}$ plasmid was essential for $R$. equi disease development among susceptible horses. Strains lacking the $85-90 \mathrm{~Kb}$ plasmid were less virulent to horses and mice (Takai et al. 1993, Guiguerre et al. 1999). The aim of this study was evaluate the virulence of R. equi isolated from human, horses and environment for mice.

\section{MATERIALS AND METHODS}

The pathogenicity test in mice, used eight Rhodococcus equi strains isolated from sick foals; four strains from feces, two from soil of pasture in an endemic horse breeding farm; two R. equi strains obtained from human imunossupressed patients and $R$. equi ATCC $33701 \mathrm{P}+\mathrm{e}$ 33701 P- (Table 1). For molecular characterization of Vap A gene, the $R$. equi isolates were submitted to PCR assays according with methods described previously (Takai et al. 1995). The samples were grown in ovine blood agar and incubated at $37^{\circ} \mathrm{C}$ for $48 \mathrm{~h}$. Colonies from these cultures were transferred into tubes with BHI (Brain Heart Infusion) and the suspension was adjusted to Mac Farland Standart 1.

Table 1. Virulence of Rhodococcus equi strains inoculated in immunossupressed (I) and no immunossupressed (NI) mice

\begin{tabular}{|c|c|c|c|c|}
\hline \multirow[t]{2}{*}{ Strain } & \multirow[t]{2}{*}{ Source/animal or soil } & \multirow[t]{2}{*}{ VAP gene ${ }^{a}$} & \multicolumn{2}{|c|}{$\%$ mortality } \\
\hline & & & I & NI \\
\hline \multicolumn{5}{|l|}{ Control } \\
\hline ATCC $33701 \mathrm{P}$ & Control/foal & + & 60.0 & 0.0 \\
\hline ATCC $33701 \mathrm{P}$ & Control/foal & - & 0.0 & 0.0 \\
\hline \multicolumn{5}{|c|}{ Horse clinical and environmental strains } \\
\hline $96 / 93$ & Abdominal abscess/ foal & + & 50.0 & 0.0 \\
\hline $353 / 93$ & Lung abscess/ foal & + & 66.7 & 0.0 \\
\hline $389 / 93$ & Lung abscess/ foal & + & 60.0 & 0.0 \\
\hline $164 / 94$ & Lung abscess/ foal & + & 33.3 & 0.0 \\
\hline $489 / 95$ & Lung abscess/ foal & + & 62.5 & 0.0 \\
\hline $557 / 96$ & Lung abscess/ foal & + & 100.0 & 0.0 \\
\hline $54 / 97$ & Lung abscess/ foal & + & 100.0 & 0.0 \\
\hline $80 / 99$ & Lung abscess/ foal & + & 100.0 & 0.0 \\
\hline NNImagery; & Feces / foal & - & 0.0 & 0.0 \\
\hline NNContarina & Feces / foal & - & 0.0 & 0.0 \\
\hline Telaura & Feces/ dam & - & 0.0 & 0.0 \\
\hline C1 égua & Feces/ dam & - & 0.0 & 0.0 \\
\hline Pasto 1 & Pasture/soil & - & 0.0 & 0.0 \\
\hline \multicolumn{5}{|c|}{ Human clinical strains } \\
\hline $15 / 99 \mathrm{H}+$ & Pneumonia/human & + & 100.0 & 0.0 \\
\hline 15/99 H- & Pneumonia/human & - & 83.3 & 0.0 \\
\hline
\end{tabular}

$\overline{\mathrm{a}}+$ Positive results on PCR, - negative results on PCR.

The imunossupressed murine model described by Multimer \& Woolcock (1982) was used in this study. In brief, the imunossuppression in 4 to 5 -week-old mice with $20-25 \mathrm{~g}$ was achieved by intraperitoneal inoculation of cyclophosphamide $(80 \mathrm{mg} / \mathrm{g}$ body weight) on challenge day and the next 3 days. $R$. equi was inoculated into the lateral tail vein and the inoculum range was $1.5 \times 10^{6}$ to $1.25 \times 10^{9}$ cells in $0.2 \mathrm{ml}$ of $\mathrm{BHI}$ suspension. The animals of the control group were inoculated with bacterial free BHI. Each $R$. equi isolate were inoculated six normal and 12 immunossuppressed mice. The control group treated and untreated with cyclophosphamide consisted of six animals.

The pathological changes and viability of $R$. equi cells in the liver of mice was verified after the 3rd, 6th and 10th day after bacterial inoculation of $R$. equi isolates from horse clinical samples, horse feces and soil of pasture; and 1st, 4 th and 6th day after inoculation of $R$. equi isolates from human patients. The animals were sacrificed, necropsied and examinated to observe macroscopic changes, and liver fragments were removed for histopathological analysis and enumeration of $R$. equi $\mathrm{CFU} / \mathrm{g}$ in the hepatic content of inoculated mice. Twenty-five microliters of hepatic content was streaked in two plates of ovine blood agar and kept for $48 \mathrm{~h}$ at $37^{\circ} \mathrm{C}$. Blood samples were collected from the control group at 4th and 10th day after inoculation to make a blood leukocyte count. The results were analyzed by the chi $\left(\chi^{2}\right)$ test. 


\section{RESULTS}

Results in Table 1 demonstrate that $81.5 \%$ of cyclophosphamide treated mice died due to equine Rhodococcus equi isolates infection. In necropsy, since the sixth day after inoculation with virulent equine strains was observed lesions in the liver and spleen in cyclophosphamide treated mice. The same lesions were present in inoculated mice with human isolates. The histopathological analysis of the liver presented multifocal granulomatous hepatitis. Histopathological changes were characterized by infiltrate of macrophages and pyogranulomatous lesions, but avirulent strains caused weak hepatic lesions without granuloma formation. The evaluation of $R$. equi counts (CFU) in the hepatic tissue showed differences among cyclophosphamide treated and untreated mice. Clearance of $R$. equi cells from the hepatic tissue was reduced among cyclophosphamide treated mice. Differences in the results of bacterial survival assays were statistically significant $(\mathrm{p}<0.0001)$ and proved a high susceptibility of immunocompromised hosts to $R$. equi infection. Strains isolated from foal clinical specimens, all carrying the $85-90 \mathrm{~Kb}$ virulence plasmid were able to persist longer in the hepatic tissues of cyclophosphamide treated mice. In contrast to the ATCC $33701 \mathrm{P}+$, ATCC 33701P- and human isolates results; data demonstrate that the CFU number of clinical and environmental horse isolates increased in the 6 th day after bacterial challenge. However, in the 10th experimental day, the R. equi ATTC and horse isolates were reduced in the liver of inoculated mice. Human $R$. equi isolates show a increasing in bacterial number at the 10 th after inoculation.

\section{DISCUSSION}

Death of cyclophosphamide treated mice occurred only when challenged with $85-90 \mathrm{~Kb}$ plasmid-positive isolates, although human Rhodococcus equi isolates killed mice independent of the presence of the virulence plasmid. This date is different from previous reports, where the human $R$. equi isolates were only virulent to mice when carrying virulence plasmid (Meijer et al. 2004).

Liver and spleen lesions in mice, inoculated with virulent $R$. equi, may be caused by a diffuse proliferation of macrophages and epithelioid cells, as well as hepatic necrosis due to thrombosis and pyogranulomatous lesions (Madarame et al. 1997). Avirulent strains may cause weak hepatic lesions without granuloma formation (Madarame et al. 1997, Guiguerre et al. 1999).

The ability of R. equi to cause infection and death in foals and mice experimentally inoculated was related to survive and multiply within macrophages (Takai et al. 1993, Madarame et al. 1997, Takai et al. 1999). The animals with a sound immune system did not die naturally, independently of the presence of virulence plasmids and of the bacterial number in their hepatic tissue. Many authors also suggest the presence of $R$. equi in inoculated animals without pathological manifestations (Multimer \& Woolcock 1982, Yager et al. 1991, Lazzari et al. 1997). Previous investigations demonstrated $R$. equi lethality in immunocompetent mice (Takai et al. 1999). Our data demonstrated the effect of immunodeficiency on resistance to $R$. equi infection in mice. The cyclophosphamide helped human and foal clinical $R$. equi isolates to turn virulent to Swiss mice. However the mechanism which cyclophosphamide induces immunosuppression and increase of mortality rates to infected mice remains unknown. Data demonstrated that the cyclophosphamide inhibited neutrophil production in mice, as previously observed in dogs (Madarame et al. 1997). Results of this paper support the findings in literature where increased lethality of $R$. equi in mice was associated with immunosuppression (Bowles et al. 1989a,b, Yager et al. 1991, Multimer \& Woolcock 1992, Hondalus \& Mussel 1994). Further studies are necessary to determine the cyclophosphamide effect in phagocytosis process.

This study showed that $R$. equi containing $85-90 \mathrm{~Kb}$ plasmids such as the ATCC $33701 \mathrm{P}+$ strain, were virulent to foal and mice. Only cyclophosphamide treated mice died due to $R$. equi infection. However, death of cyclophosphamide treated mice was related with the presence of the $85-90 \mathrm{~Kb}$ virulence plasmid just in $R$. equi strains obtained from foals. On the other hand, $R$. equi strains isolated form HIV reactors were virulent to immunossupressed mice independent of the presence of 85$90 \mathrm{~Kb}$ plasmid. The majority of $R$. equi clinical isolates from patients with or without AIDS did not carry virulence plasmid and were avirulent to mice (Takai et al. 1999).

Acknowledgments.- This study was supported by grant from CNPq, CAPES, FAPERGS, FAPERJ, FATEC, PRONEX and SR2-UERJ.

\section{REFERENCES}

Bowles P.M., Woolcock J.B. \& Multimer M.D. 1989a. The effect of immunosuppression on resistance to Rhodococcus equi in mice. Vet. Immunol. Immunopat. 22:369-378.

Bowles P.M., Woolcock J.B. \& Multimer M.D. 1989b. Early events associated with experimental infection of the murine lung with Rhodococcus equi. J. Comp. Pat. 101:11-420.

Guigerre S., Hondalus M.K., Yager J.A., Darrah P., Moser D.M. \& Prescott J.F. 1999. Role of the $85 \mathrm{~Kb}$ plasmid and plasmid encoded virulence protein $\mathrm{A}$ in intracellular survival and virulence of Rhodococcus equi. Infect. Imun. 67:3548-3557.

Hines S.A., Kanaly S.T., Byrne B.A. \& Palmer, G.H. 1997. Immunity to Rhodococcus equi. Vet. Microbiol. 56:177-185.

Hondalus M.K., \& Mossel D.M. 1994. Survival and replication of Rhodococcus equi in macrophages. Infect. Immun. 62:4167-4175.

Kedlaya I., Ing M.B. \& Wong, S.S. 2001. R. equi infections in immunocompetent hosts: case report and review. Clin. Infect. Dis. 32:39-47

Lazzari A., Vargas A.C., Dutra V., Araujo L.A., Castagna L. \& Costa M.M. 1997. Pathogenicity of clinical and environmental Rhodococcus equi isolates in mice. Vet. Téc. 4:24-30.

Madarame H., Takai S., Matsumoto C., Minamiyama K., Sasaki Y., Tsubaki S., Hasegawa Y. \& Nakane A. 1997. Virulent and avirulent Rhodococcus equi infection in T-cell deficient athymic nude mice: pathologic, bacteriologic and immunologic responses. FEMS Immunol. Med. Microbiol. 17:251-262.

Martens J.G., Martens R.J. \& Renshaw H.W. 1988. Rhodococcus (Corynebacterium) equi: Bactericidal capacity of neutrophils from neonatal and adult horse. Am. J. Vet. Res. 49:295-299.

Meijer W.G. \& Prescott J.F. 2004. Rhodococcus equi. Vet Res. 35(4):383-96.

Multimer M.D. \& Woolcock J.B. 1982. Experimental Corynebacterium equi infection in mice. J. Rep. Fert. 32:469-472.

Nordmann P., Zinzendorf N., Keller M., Lair I., Ronco E. \& Guenounou M. 1994. Interaction of virulent and non-virulent Rhodococcus equi human 
isolates with phagocytes, fibroblast- and epithelial-derived cells. FEMS Immunol Med. Microbiol. 9(3):199-205.

Ozgur Y., Ikiz S., Carioglu B., Ligas A. \& Takai S. 2000. Two cases of dead foals associated with R. equi pneumonia in Turkey. J. Eq. Sci. 11:1-5.

Sellon D.C., Besser T.E., Vivrette S.L. \& Mcconnico R.S. 2001. Comparison of nucleic acid amplification, serology and microbiological culture of diagnosis of $R$. equi pneumonia in foals. J. Clin. Microbiol. 39:12891293.

Takai S., Ikeda T., Sasaki Y., Watanabe,Y., Ozawa T., Tsubaki S. \& Sekizaki T. 1995. Identification of virulent Rhodococcus equi by amplification of gene coding for 15-17 kDa antigen. J. Clin. Microbiol. 33:1624-1627.

Takai S., Anzai T., Sasaki Y., Tsubaki S. \& Kamada M. 1993. Virulence of
Rhodococcus equi isolated from lesions of infected foals. Bull. Eq. Res. Inst. 30:9-14.

Takai S., Fukunaga N., Ochiai S., Sakai T., Sasaki Y. \& Tsubaki S. 1996. Isolation of virulent and intermediately virulent Rhodococcus equi from soil and sand on parks and yards in Japan. J. Vet. Med. Sci. 58:669-672.

Takai S., Kobayashi C., Murakami K., Sasaki Y. \& Tsubaki S. 1999. Live virulent Rhodococcus equi, rather than killed and avirulent, elicits protective immunity to $R$. equi infection in mice. FEMS Immunol. Med. Microbiol. 24:1-9.

Yager J.A., Prescott C.A., Kramar D.P., Hannah H., Balson G.A. \& Croy B.A. 1991. The effect of experimental infection with Rhodococcus equi on immunodeficient mice. Vet. Microbiol. 28:363-376. 